\title{
Effect of zinc supplementation in children with asthma: a randomized, placebo-controlled trial in northern Islamic Republic of Iran
}

\author{
J. Ghaffari, ${ }^{1}$ A. Khalilian, ${ }^{2}$ E. Salehifar, ${ }^{3}$ E. Khorasani ${ }^{1}$ and M.S. Rezaii ${ }^{1}$
}

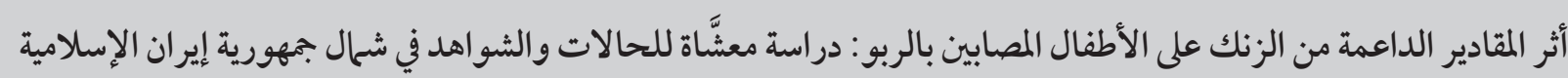

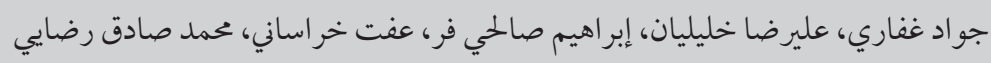

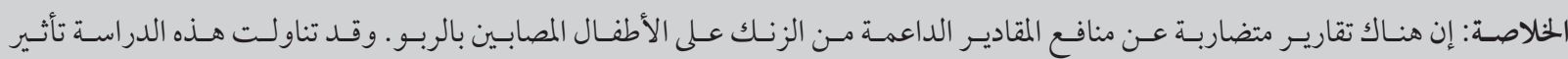

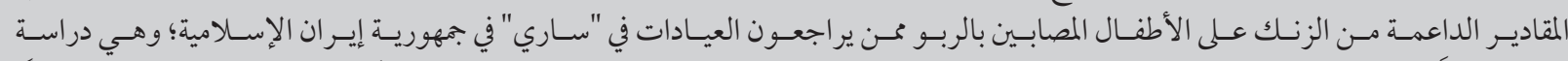

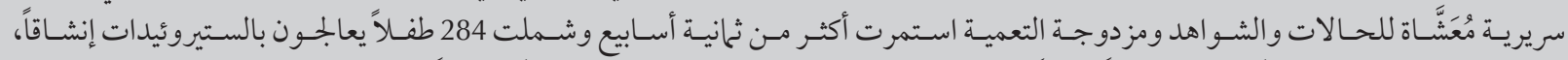

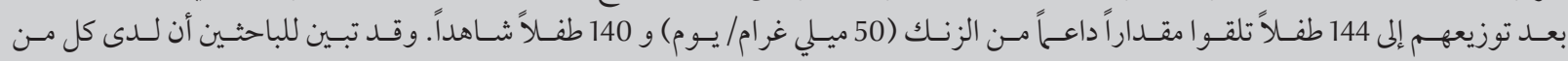

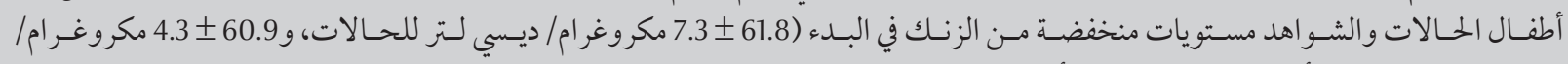

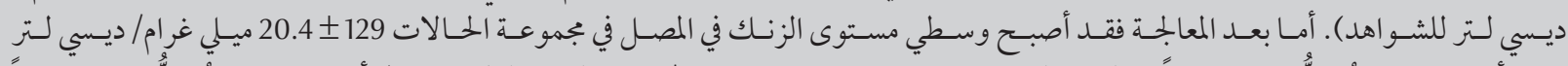

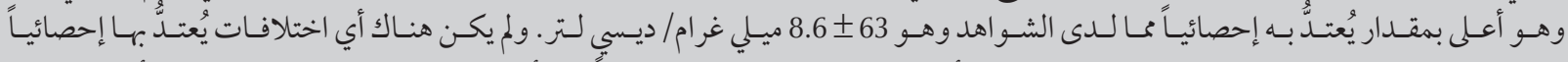

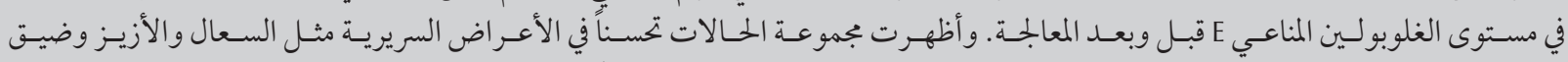

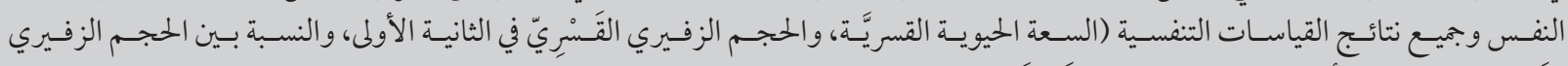

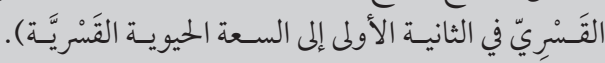

ABSTRACT There are conflicting reports about the benefits of zinc supplements in childhood asthma. This study examined the effect of zinc supplementation in children with asthma attending an outpatient clinic in Sari, Islamic Republic of Iran. In a randomized, double-blind, placebo-controlled clinical trial over 8 weeks, 284 children on inhaled steroids were allocated to receive zinc supplements $(50 \mathrm{mg} /$ day $)(n=144)$ or placebo $(n=140)$. Cases and controls had low initial serum zinc concentrations [61.8 (SD 7.3) $\mu \mathrm{g} / \mathrm{dL}$ and 60.9 (SD 4.3) $\mu \mathrm{g} / \mathrm{dL}$. After treatment, mean serum zinc level in the case group was significantly higher [129 (SD 20.4) $\mu \mathrm{g} / \mathrm{dL}$ ] than in the controls [63 (SD 8.6) $\mu \mathrm{g} / \mathrm{dL}$ ]. There were no significant differences in IgE levels before and after treatment. The case group showed significant improvements in clinical symptoms such as cough, wheezing and dyspnoea and in all spirometry parameters (FVC, FEV1 and FEVI/FVC).

Effet de la supplémentation en zinc chez des enfants asthmatiques : essai randomisé et contrôlé par placebo dans le nord de la République islamique d'Iran

RÉSUMÉ Les informations concernant les bénéfices d'une supplémentation en zinc chez l'enfant asthmatique sont contradictoires. L'étude a examiné les effets d'une supplémentation en zinc chez des enfants asthmatiques suivis dans un service de consultations externes à Sari (République islamique d'Iran). Dans un essai clinique randomisé d'une durée de 8 semaines, en double aveugle et contrôlé contre placebo, 284 enfants sous corticostérö̈des inhalés ont été répartis entre un groupe recevant une supplémentation en zinc ( $50 \mathrm{mg} / \mathrm{jour})(\mathrm{n}=144)$ et un groupe sous placebo $(n=140)$. Les cas comme les témoins présentaient des concentrations sériques en zinc initiales faibles $[61,8$ (E.T. 7,3) $\mu \mathrm{g} / \mathrm{dL}$ et 60,9 (E.T. 4,3) $\mu \mathrm{g} / \mathrm{dL}]$. Après le traitement, la concentration sérique en zinc moyenne dans le groupe des cas était nettement supérieure [129 (E.T. 20,4) $\mu \mathrm{g} / \mathrm{dL}$ ] par rapport au groupe des témoins [63 $(E . T .8,6) \mu \mathrm{g} / \mathrm{dL}$. Aucune différence significative n'a été observée dans les taux d'IgE avant et après le traitement. Dans le groupe des cas, des améliorations significatives des symptômes cliniques ont été observées, notamment la toux, les sifflements respiratoires, la dyspnée et tous les paramètres spirométriques (CVF, VEMS et VEMS/CVF).

${ }^{7}$ Department of Paediatrics, Antimicrobial Resistant Nosocomial Infection Research Center; ${ }^{2}$ Department of Statistics; ${ }^{3}$ Department of Pharmacology, Mazandaran University of Medical Sciences, Sari, Islamic Republic of Iran (Correspondence to M.S. Rezaii: drmsrezaii@yahoo.com).

Received: 01/06/13; accepted: 06/01/14 


\section{Introduction}

Allergic disorders such as asthma, allergic rhinitis, atopic dermatitis and even chronic urticaria have a high prevalence of morbidity, with significant effects on individuals' quality of life and high economic costs for families and nations (1). Bronchial asthma is a chronic inflammatory disease of the respiratory tract system and is more common in children than adults (1). The prevalence of asthma varies in different regions of the world. In the Islamic Republic of Iran a meta-analysis has estimated the prevalence of asthma in the country overall to be about $7.6 \%$ (2), while in the north of the country, where this study was carried out, a prevalence of $12 \%$ was reported (3).

The reported prevalence of asthma has been increasing rapidly in recent decades. The etiology of asthma is not clear, and genetic and environmental factors have been implicated in its pathogenesis (4). One hypothesis for the increasing rates of asthma are low consumption of antioxidant foods or increased oxidative stress $(1,5,6)$. Different studies suggested that trace elements might be involved in inflammatory processes such as asthma ( 1 , 4). Zinc levels have been shown to be low in the serum, hair and sputum of patients with asthma $(1,6-8)$. Trace elements such as selenium and zinc are essential components of antioxidant enzymes and are required to inhibit the production of the free radicals that are thought to aggravate asthma $(8,9)$. Zinc is involved in cell and tissue growth and plays an important role in DNA and protein synthesis. Furthermore zinc is an important element in oxidant/ antioxidant pathways and is believed to have a pivotal role in bronchial asthma pathways $(1,4,10)$. Zinc is a modulator of the immune system, decreasing the inflammatory response. It has been suggested that zinc deficiency could decrease the activity/levels of Th1 helper $\mathrm{T}$-cells and increase the activity/levels of Th2 helper T-cells in asthma (11). Consumption of zinc-containing foods by mothers during pregnancy has been shown to be associated with a lower risk of wheeze and asthma in the child (12).

There are conflicting reports about the effect of zinc supplements on childhood asthma. In a study in the Islamic Republic of Iran Pouramjad et al. showed that zinc supplements had no effect on the clinical manifestations of asthma and on pulmonary function tests (13). In contrast Biltagi et el., in Egypt, showed that consumption of omega-3 fatty acid, vitamin $\mathrm{C}$ and zinc, singly or in combination, led to significant improvements in pulmonary function tests and sputum inflammatory markers in placebo, self-controlled trials of children with asthma (14). The aim of the present study in Sari, Islamic Republic of Iran, was to examine the effect of zinc supplementation on clinical symptoms and pulmonary function tests in children with asthma.

\section{Methods}

This study was a double-blind, randomized, placebo-controlled clinical trial of the effect of zinc supplementation on clinical symptoms in zinc-deficient children with asthma in Sari, northern Islamic Republic of Iran.

\section{Sample}

The sample was selected from among patients attending the public outpatient allergy clinic at Mazandaran University of Medical Sciences between August 2010 and May 2011. The sample size was calculated based on the results of previous studies (prevalence of asthma $10 \%-12 \%)$. Patients were excluded if they had diabetes mellitus, liver or kidney disease, infections or thyroid dysfunction, or clear clinical manifestations of zinc deficiency. We also excluded children who had been taking trace elements or vitamin supplements.
The diagnosis of moderate and/ or partly controlled bronchial asthma was made based on the child's history, family history, physical examination and assessment by an allergist and clinical immunologist using Global Initiative for Asthma criteria (15). All patients in this study were using fixed inhaled steroids (moderate dose of fluticasone). Of the 345 patients assessed for eligibility, 30 did not meet the inclusion criteria, 10 declined to participate and 5 were excluded for other reasons. The remaining 300 patients were enrolled in the clinical trial and randomized to either the case $(n=155)$ or the control group $(n=145)$.

The study was approved by the ethics committee of Mazandaran University of Medical Sciences. Written informed consent was obtained from parents or guardians of the children. Because there were no clinical manifestations of zinc deficiency in our patients, there was no ethical requirement to use zinc supplements in the control group.

\section{Data collection}

The patients' clinical data were assessed by a researcher and a paediatrician. Both were blind to the treatment groups. Clinical symptoms (cough, wheezing, dyspnoea), spirometry indices and serum zinc and IgE levels were recorded before and after the intervention.

Pulmonary function testing was performed by an expert technician for forced vital capacity (FVC), forced expiratory volume in 1 second (FEV1) and FEV1/FVC. The measures were performed without the use of a bronchodilator.

A $5 \mathrm{~mL}$ sample of blood was taken from all patients. Blood was centrifuged at $2000 \mathrm{rpm}$ for 15 minutes. Serum zinc level were measured by atomic absorption spectroscopy (Zeeman, Varian) and expressed in $\mu \mathrm{g} / \mathrm{dL}$. Complete blood count, eosinophil count and serum total IgE level was performed for all patients. 


\section{Intervention}

After recruitment patients judged to have moderate asthma with associated zinc deficiency $(<70 \mu \mathrm{g} / \mathrm{dL})$ according to the allergist and clinical immunologist were randomized by a paediatrician to the intervention (zinc supplements, $50 \mathrm{mg} /$ day) or control (placebo) group. Patients received the drug or placebo from the pharmacy and were blind to the treatment. Treatments continue for 8 weeks. Both groups received inhaled fluticasone spray. If a patient had unrelieved symptoms, they were advised to use a short-acting beta- 2 agonist (salbutamol).

\section{Statistical analysis}

Analysis was done to determine the clinical improvement and spirometry alteration between the 2 groups. All results are given as the mean and standard deviation (SD) value and data analysis was performed with SPSS software, version 17 statistical program. Data were analysed using paired t-test (for comparing before and after intervention data), independent-test (for comparison between the 2 groups) and the chisquared test (for qualitative variables). $P$-values $<0.05$ were assumed to be statistically significant.

\section{Results}

\section{Eligible patients}

Table 1 shows the age and sex distribution of the 300 enrolled patients (155 cases and 145 controls). There were more boys than girls (59\% versus $41 \%$ ). The mean age was 7.6 (SD 1.6) years and 7.8 (SD 0.5) years respectively in the case and control groups.

Of the 155 patients in the case group 11 did not receive the allocated intervention. After the intervention a further 4 children were lost to followup and 6 discontinued treatments (of drug and decreased inhaler steroids). Of the 145 in the control group 5 did not receive the allocated intervention. After

\begin{tabular}{|c|c|c|c|c|c|c|}
\hline \multirow[t]{2}{*}{ Variable } & \multicolumn{2}{|c|}{ Case group } & \multicolumn{2}{|c|}{ Control group } & \multicolumn{2}{|c|}{ Total } \\
\hline & No. & $\%$ & No. & $\%$ & No. & $\%$ \\
\hline Total & 144 & 100 & 140 & 100 & 284 & 100 \\
\hline \multicolumn{7}{|l|}{ Sex } \\
\hline Female & 74 & 51 & 67 & 49 & 141 & 41 \\
\hline Male & 70 & 48 & 73 & 51 & 143 & 59 \\
\hline \multicolumn{7}{|l|}{ Age (years) } \\
\hline $5-10$ & 88 & 61 & 82 & 59 & 170 & 60 \\
\hline $11-15$ & 56 & 49 & 58 & 41 & 114 & 40 \\
\hline Mean (SD) & \multicolumn{2}{|c|}{$7.6(1.6)$} & \multicolumn{2}{|c|}{$7.8(0.5)$} & \multicolumn{2}{|c|}{$7.8(1.2)$} \\
\hline
\end{tabular}

$S D=$ standard deviation .

the intervention 3 were lost to follow-up and 4 discontinued the intervention (of placebo and decreased inhaler steroid). The data were therefore analysed for the 144 cases and 140 controls who completed the study and not for the whole group on the basis of intention to treat.

\section{Mean serum zinc levels}

The mean serum zinc level was 61.8 (SD 7.3) $\mu \mathrm{g} / \mathrm{dL}$ and 60.9 (SD 4.3) $\mu \mathrm{g} /$ $\mathrm{dL}$ in the case and control groups respectively before treatment (Table 2). After treatment the serum mean levels of zinc increased to 129 (SD 20.4) $\mu \mathrm{g} /$ $\mathrm{dL}$ in the case group compared with 63 (SD 8.6) $\mu \mathrm{g} / \mathrm{dL}$ in the controls, and this was a significant difference $(P<0.001)$. There was no significant difference in IgE levels in both groups before and after treatment $(P<0.05)$ (Table 2).

\section{Clinical symptoms}

Clinical symptoms evaluated in this study are shown in Table 3. There were significant improvements in the case group compared with the control group in all the clinical symptoms evaluated: cough $[$ relative risk $(\mathrm{RR})=2.3 ; 95 \% \mathrm{CI}$ : 1.3-4.1] $(P=0.003)$, wheezing ( $\mathrm{RR}=$ 3.6; 95\% CI: 1.8-7.4) $(P<0.001)$ and dyspnoea $(\mathrm{RR}=4.2 ; 95 \% \mathrm{CI}: 1.9-8.7)$ $(P<0.001)$.

\section{Spirometry parameters}

Table 4 shows the spirometry parameters before and after 8 weeks treatment with zinc supplements compared with the control group. Zinc supplementation had a significant effective on all parameters of spirometry including FVC, FEV1 and FEV1/FVC ratio. For example FEV1/FVC ratio before and after the intervention was 73.1 (SD 3.6) and 83.4 (SD 4.7) respectively in the case group $(P=0.007)$ and 74.7 (SD 3.9) and 77.8 (SD 4.6) respectively in the control group.

\section{Discussion}

Zinc and copper are required for optimal activity of the immune system and it has been shown that low levels of these trace elements are important factors in acute and chronic inflammatory states such as bronchial asthma (16). However, the evidence regarding the clinical efficacy of zinc supplementation on children with asthma is conflicting. This study was therefore designed to examine the effects of zinc on clinical symptoms and spirometry parameters in bronchial asthma.

We demonstrated that zinc supplementation at $50 \mathrm{mg} /$ day for 8 weeks had a significant beneficial effect on both clinical symptoms and lung function in bronchial asthma patients. In other studies, the relationship between serum zinc and bronchial asthma remains doubtful $(6,16,17)$ or controversial (18). In another study in the 


\begin{tabular}{|c|c|c|c|c|c|c|}
\hline \multirow[t]{3}{*}{ Parameter } & \multicolumn{3}{|c|}{$\begin{array}{l}\text { Case group } \\
(n=144)\end{array}$} & \multicolumn{3}{|c|}{$\begin{array}{l}\text { Control group } \\
\quad(n=140)\end{array}$} \\
\hline & Before & After & $P$-value ${ }^{a}$ & Before & After & $P$-value ${ }^{\text {a }}$ \\
\hline & Mean (SD) & Mean (SD) & & Mean (SD) & Mean (SD) & \\
\hline Serum zinc $(\mu \mathrm{g} / \mathrm{dL})$ & $61.8(7.3)$ & $129(20.4)$ & $<0.001$ & $60.9(4.3)$ & $63(8.6)$ & 0.701 \\
\hline Serum IgE (IU/L) & $119(22)$ & $106(17)$ & 0.423 & 109 (18) & $103(16)$ & 0.648 \\
\hline
\end{tabular}

${ }^{a}$ Before versus after, paired $t$-test.

$S D=$ standard deviation.

Islamic Republic of Iran Pouramjad et al. showed that zinc supplementation (50 mg every other day) had no significant effect on respiratory factors such as spirometry (12). We used a higher dose of zinc sulphate (50 mg every day), however, which might explain the positive effect of zinc supplementation in our study. Furthermore, we evaluated both lung function and clinical symptoms. Biltagi et al. showed a positive effect not only of zinc supplementation but also supplementation with omega-3 fatty acids and vitamin $\mathrm{C}$ in children with moderate asthma (14), and combined therapy was more effective than single therapies.

Before the intervention all the asthmatic children in our study had low of serum zinc concentrations $(<70 \mu \mathrm{g} /$ dL). Studies have suggested that allergic diseases such as asthma, leukaemia and coronary artery ectasia are associated with deficiencies of trace elements such as selenium and zinc $(14,19,20)$. Furthermore it has been shown that hair zinc levels are lower in children with recurrent wheeze compared with healthy controls and are negatively correlated with wheezing episodes in the last 6 months (21). Although erythrocyte zinc levels were not significantly decreased in asthma patients compared with a healthy group of children, there was a significant decrease in patients hospitalized with asthma attacks (22).

It has been suggested that zinc deficiency can reduce antioxidant function and lead to exacerbation of bronchial asthma. Soutar et al. reported that limitation of zinc intake was associated with a higher risk of asthma attacks (23). Therefore it seems that zinc could be an effective trace element in bronchial asthma patients. It has been reported that zinc decreases the incidence and prevalence of acute respiratory tract infection and the severity of symptoms of the common cold $(24,25)$. El-Kholy et al. reported that adequate dietary intake of zinc and zinc supplementation might decrease the severity of asthmatic attacks (26). Animal studies also demonstrated that zinc supplements reduced inflammatory and airway hyper-responsiveness (27). Prasad et al. showed that zinc decreased oxidative stress and nuclear transcription factor NF-kB activation in isolated mononuclear cells via induction of zinc finger protein A20 (28).

In the present study we were unable to evaluate bronchial epithelial levels of superoxide dismutase, an enzyme which is deficient in asthma patients, but has been hypothesized that zinc might increase the activity of the enzyme similar to inhaler steroids which have been used in these patients (29). Therefore, it is possible that zinc and inhaler steroids have synergistic effects.

Although in this study serum total IgE levels decreased in the case group after zinc treatment, the difference was not significant. It seems that changes in serum total $\operatorname{IgE}$ levels may not be an important factor in bronchial asthma patients. Nevertheless Morgan et al.

\begin{tabular}{|c|c|c|c|c|c|c|c|c|c|c|c|c|}
\hline \multirow[t]{3}{*}{ Symptom } & \multicolumn{5}{|c|}{$\begin{array}{l}\text { Case group } \\
(n=144)\end{array}$} & \multicolumn{5}{|c|}{$\begin{array}{l}\text { Control group } \\
\qquad(n=140)\end{array}$} & \multicolumn{2}{|c|}{ Statistical analysis } \\
\hline & \multicolumn{2}{|c|}{ Before } & \multicolumn{2}{|c|}{ After } & \multirow[t]{2}{*}{$P$-value ${ }^{a}$} & \multicolumn{2}{|c|}{ Before } & \multicolumn{2}{|c|}{ After } & \multirow[t]{2}{*}{$P$-value ${ }^{\mathrm{a}}$} & \multirow[t]{2}{*}{$\operatorname{RR}(95 \% \mathrm{Cl})$} & \multirow[t]{2}{*}{$P$-value ${ }^{\mathrm{b}}$} \\
\hline & No. & $\%$ & No. & $\%$ & & No. & $\%$ & No. & $\%$ & & & \\
\hline Cough & 127 & 88 & 101 & 70 & 0.004 & 112 & 80 & 103 & 74 & 0.427 & $2.3(1.3-4.1)$ & 0.003 \\
\hline Wheezing & 94 & 65 & 68 & 47 & 0.002 & 88 & 63 & 81 & 58 & 0.638 & $3.6(1.8-7.4)$ & $<0.001$ \\
\hline Dyspnoea & 56 & 39 & 35 & 24 & 0.003 & 57 & 41 & 49 & 35 & 0.537 & $4.2(1.9-8.7)$ & $<0.001$ \\
\hline $\begin{array}{l}\text { Partially controlled } \\
\text { asthma }^{c}\end{array}$ & 144 & 100 & 73 & 51 & $<0.001$ & 140 & 100 & 112 & 80 & 0.261 & $2.0(1.4-2.8)$ & $<0.001$ \\
\hline
\end{tabular}

${ }^{a}$ Before versus after, $x^{2}$-test; ${ }^{b}$ Case versus control group, independent $t$-test.

'Daytime symptoms more than twice/week; limitations of activities and nocturnal symptoms/activities; need for relief/rescue therapy more than twice/week; lung function (PEF or FEVI) $<80 \%$ of predicted or personal best.

$R R=$ relative risk; $95 \% \mathrm{CI}=$ confidence interval. 


\begin{tabular}{|c|c|c|c|c|c|c|}
\hline \multirow[t]{2}{*}{ Parameter } & \multicolumn{3}{|c|}{$\begin{array}{c}\text { Case group } \\
(n=144)\end{array}$} & \multicolumn{3}{|c|}{$\begin{array}{l}\text { Control group } \\
\qquad(n=140)\end{array}$} \\
\hline & $\begin{array}{c}\text { Before } \\
\text { Mean (SD) }\end{array}$ & $\begin{array}{c}\text { After } \\
\text { Mean (SD) }\end{array}$ & $P$-value ${ }^{a}$ & $\begin{array}{c}\text { Before } \\
\text { Mean (SD) }\end{array}$ & $\begin{array}{c}\text { After } \\
\text { Mean (SD) }\end{array}$ & $P$-value ${ }^{a}$ \\
\hline FVC (L) & $87.2(3.4)$ & $96.7(5.6)$ & $<0.001$ & $86.1(3.3)$ & $93.4(4.9)$ & 0.649 \\
\hline FEV1 (L) & $71.1(3.8)$ & $84.7(3.9)$ & 0.002 & $72.8(4.2)$ & $73.1(4.2)$ & 0.852 \\
\hline FEV1/FVC (FEV1\%) & $73.1(3.6)$ & $83.4(4.7)$ & 0.007 & $74.7(3.9)$ & $77.8(4.6)$ & 0.784 \\
\hline
\end{tabular}

${ }^{a}$ Before versus after, paired $t$-test.

$S D=$ standard deviation; $F V C=$ forced vital capacity; $F E V I=$ forced expiratory volume in 1 second .

showed zinc supplementation decreased airways hyper-responsiveness and serum IgE levels in a mouse model of allergic airway inflammation, and suggested that zinc supplements might have an anti-inflammatory effect via inhibition of the NF-kB pathway which leads to a decrease of serum IgE levels (27). Lang et al.'s study showed that zinc supplementation caused decreased eosinophil and lymphocyte levels in the bronchoalveolar lavage of mice (30).

There were some limitations to our study. The sample size was small, there was no assessment of patients' diet and no separate evaluation was made of cases of mild and severe asthma. We did not evaluate other antioxidants such as selenium and magnesium or inflammatory markers in respiratory tract secretions.

\section{Conclusions}

In this study we showed that zinc supplementation at $50 \mathrm{mg} /$ day in children with moderate asthma with zinc deficiency significantly improved both clinical symptoms and lung function. We recommend that any asthma patients with zinc deficiency use zinc supplements. Further studies with larger samples and cross-sectional methods are needed to further understanding the relationship between zinc supplement and bronchial asthma

\section{Acknowledgements}

Funding: this study was a resident thesis (Dr Effat Khorasani) supported by a financial grant from the Mazandaran University of Medical Sciences (thesis no. 1153). RCT registration number: IRCT $201105316660 \mathrm{n} 1$

Competing interests: None declared.

\section{References}

1. Nurmatov U, Devereux G, Sheikh A. Nutrients and foods for the primary prevention of asthma and allergy: systematic review and meta-analysis. J Allergy Clin Immunol. 2011 Mar;127(3):724-33, el-30. PMID:21185068

2. Ghaffari J, Aarabi M. The prevalence of pediatric asthma in the Islamic Republic of Iran: a systematic review and metaanalysis. J Pediatr Rev. 2013;1:2-11.

3. Ghaffari J. Prevalence of asthma, allergic rhinitis and eczema in elementary schools in Sari (Iran). Caspian J Intern Med. 2012;3:372-6.

4. Fraenkel DJ, Holgate ST. Etiology of asthma: pathology and mediators. In: Biermann CW, et al., editors. Allergy, asthma and immunology from infancy to adulthood. 3rd ed. Philadelphia: WB Saunders; 1996. pp. 443-72.

5. Chatzi L, Torrent M, Romieu I, Garcia-Esteban R, Ferrer C, Vioque J, et al. Diet, wheeze, and atopy in school children in Menorca, Spain. Pediatr Allergy Immunol. 2007 Sep;18(6):480-5. PMID:17680906

6. Kocyigit A, Armutcu F, Gurel A, Ermis B. Alterations in plasma essential trace elements selenium, manganese, zinc, copper, and iron concentrations and the possible role of these elements on oxidative status in patients with childhood asthma. Biol Trace Elem Res. 2004 Jan;97(1):31-41. PMID:14742898

7. Laker M. On determining trace element levels in man: the uses of blood and hair. Lancet. 1982 Jul 31;2(8292):260-2. PMID:6124683
8. Vural H, Uzun K, Uz E, Koçyigit A, Cigli A, Akyol O. Concentrations of copper, zinc and various elements in serum of patients with bronchial asthma. J Trace Elem Med Biol. 2000 Jun;14(2):88-91. PMID:10941719

9. De Raeve HR, Thunnissen FB, Kaneko FT, Guo FH, Lewis M, Kavuru MS, et al. Decreased Cu, Zn-SOD activity in asthmatic airway epithelium: correction by inhaled corticosteroid in vivo. Am J Physiol. 1997 Jan;272(1 Pt 1):L148-54. PMID:9038914

10. Heo Y, Parsons PJ, Lawrence DA. Lead differentially modifies cytokine production in vitro and in vivo. Toxicol Appl Pharmacol. 1996 May;138(1):149-57. PMID:8658504

11. Miller AL. The etiologies, pathophysiology, and alternative/ complementary treatment of asthma. Altern Med Rev. 2001 Feb;6(1):20-47. PMID:11207455

12. Devereux G, Turner SW, Craig LC, McNeill G, Martindale $\mathrm{S}$, Harbour PJ, et al. Low maternal vitamin $\mathrm{E}$ intake during pregnancy is associated with asthma in 5-year-old children. Am J Respir Crit Care Med. 2006 Sep 1;174(5):499-507. PMID:16763215

13. Pouramjad SM, Egtesadi SH, Javad Mousavi SA, Nourmohammadi I, Yazdani R. Study of zinc serum concentration and effect of zinc supplementation on lung function in asthmatic patients. J Iran Univ Med Sci. 2009;15(60-61):55-61.

14. Biltagi MA, Baset AA, Bassiouny M, Kasrawi MA, Attia M. Omega-3 fatty acids, vitamin $C$ and $Z n$ supplementation in asthmatic children: a randomized self-controlled study. Acta 
Paediatr. 2009 Apr;98(4):737-42. PMID:19154523 [Article retracted in Acta Paediatr. 2012 Aug;101(8):891].

15. Global strategy for asthma management and prevention. Update 2010. Global Initiative for Asthma, 2010 (http://www. ginasthma.org/local/uploads/files/GINA_Report_2010_1.pdf, accessed 22 February).

16. Schwartz J, Weiss ST. Dietary factors and their relation to respiratory symptoms. The Second National Health and Nutrition Examination Survey. Am J Epidemiol. 1990 Jul;132(1):67-76. PMID:2356815

17. Picado C, Deulofeu R, Lleonart R, Agustí M, Mullol J, Quintó L, et al. Dietary micronutrients/antioxidants and their relationship with bronchial asthma severity. Allergy. 2001 Jan;56(1):439. PMID:11167351

18. Anetor JI, Ajose OA, Ige O, Oyeleye AO, Ojo PO. Antioxidant status of adult Nigerian asthmatics: implications for prognosis. Nutr Health. 2003;17(3):221-9. PMID:14703155

19. Kosar F, Taskapan C, Kucukbay Z. Serum levels of selenium, zinc and copper in patients with coronary artery ectasia. Indian Heart J. 2007 Jan-Feb;59(1):38-41. PMID:19098333

20. Zuo XL, Chen JM, Zhou X, Li XZ, Mei GY. Levels of selenium, zinc, copper, and antioxidant enzyme activity in patients with leukemia. Biol Trace Elem Res. 2006 Winter;114(1-3):41-53. PMID:17205986

21. Razi CH, Akelma AZ, Akin O, Kocak M, Ozdemir O, Celik A, et al. Hair zinc and selenium levels in children with recurrent wheezing. Pediatr Pulmonol. 2012 Dec;47(12):1185-91. PMID:22949381

22. Yilmaz EA, Ozmen S, Bostanci I, Misirlioglu ED, Ertan U. Erythrocyte zinc levels in children with bronchial asthma. Pediatr Pulmonol. 2011 Dec;46(12):1189-93. PMID:21815275
23. Soutar A, Seaton A, Brown K. Bronchial reactivity and dietary antioxidants. Thorax. 1997 Feb;52(2):166-70. PMID:9059479

24. Sazawal S, Black RE, Jalla S, Mazumdar S, Sinha A, Bhan MK. Zinc supplementation reduces the incidence of acute lower respiratory infections in infants and preschool children: a double-blind, controlled trial. Pediatrics. 1998 Jul;102(1 Pt 1):1-5. PMID:9651405

25. Prasad AS, Fitzgerald JT, Bao B, Beck FW, Chandrasekar PH. Duration of symptoms and plasma cytokine levels in patients with the common cold treated with zinc acetate. A randomized, double-blind, placebo-controlled trial. Ann Intern Med. 2000 Aug 15;133(4):245-52. PMID:10929163

26. el-Kholy MS, Gas Allah MA, el-Shimi S, el-Baz F, el-Tayeb H, Abdel-Hamid MS. Zinc and copper status in children with bronchial asthma and atopic dermatitis. J Egypt Public Health Assoc. 1990;65(5-6):657-68. PMID:2134100

27. Morgan $\mathrm{Cl}$, Ledford JR, Zhou P, Page K. Zinc supplementation alters airway inflammation and airway hyperresponsiveness to a common allergen. J Inflamm (Lond). 2011;8:36. PMID:22151973

28. Prasad AS, Bao B, Beck FW, Kucuk O, Sarkar FH. Antioxidant effect of zinc in humans. Free Radic Biol Med. 2004 Oct 15;37(8):1182-90. PMID:15451058

29. De Raeve HR, Thunnissen FB, Kaneko FT, Guo FH, Lewis M, Kavuru MS, et al. Decreased Cu,Zn-SOD activity in asthmatic airway epithelium: correction by inhaled corticosteroid in vivo. Am J Physiol. 1997 Jan;272(1 Pt 1):L148-54. PMID:9038914

30. Lang $C$ et al. Anti-inflammatory effects of zinc and alterations in zinc transporter mRNA in mouse models of allergic inflammation. American Journal of Physiology, 2007, 292:L577L584. 